\title{
GEÓWNE ZASADY PRAWNE POLITYKI PAŃSTWA W SFERZE OCHRONY ŚRODOWISKA NA UKRAINIE
}

\author{
THE MAIN LEGAL RULES OF STATE POLICY \\ IN SPHERE OF ENVIRONMENTAL PROTECTION \\ IN UKRAINE
}

\section{STRESZCZENIE}

Artykuł dotyczy podstaw prawnych dla prowadzenia polityki ochrony środowiska na Ukrainie. Analizie poddano kluczowe akty regulujące tę sferę: Konstytucję Ukrainy, ustawę o ochronie środowiska naturalnego, „Główne zasady (Strategia) państwowej polityki ekologicznej Ukrainy do 2020 roku” oraz „Narodowy plan działań z ochrony środowiska naturalnego na lata 2011-2015". Ponadto dokonano przeglądu dostosowania prawodawstwa ukraińskiego do norm unijnych w kontekście integracji Ukrainy z Unią Europejską. Generalnie ukraińska baza prawna odpowiada wyzwaniom ekologicznym stojącym

* Instytut Stosunków Międzynarodowych, Narodowy Uniwersytet im. T. Szewczenki w Kijowie. 
przed tym państwem. Nie przekłada się to jednak na szybką poprawę stanu środowiska naturalnego na Ukrainie. Głównymi przyczynami tego jest niska efektywność organów państwowych oraz wysoki poziom korupcji.

\title{
Słowa kluczowe
}

Ukraina, polityka, środowisko naturalne, ochrona, prawodawstwo, Konstytucja, ustawy, strategia, plan działań, integracja europejska.

\begin{abstract}
The article is about main legal principles of environmental policy in Ukraine. It analyses the key acts and documents regulating this sphere: Constitution of Ukraine, the Law of Ukraine On Environmental Protection, "The Main Principles of Environmental Policy of Ukraine up to 2020" and "The National Action Plan for Environmental Protection for 2011-2015". Also, the article contains review of adaptation of Ukrainian legislation to EU standards in terms of Ukraine's integration with the EU. Generally, Ukrainian legal base corresponds to the main ecological challenges facing that country. But it does not make better the situation of environment in Ukraine. The biggest problems in this context are low efficiency of state bodies and high levels of corruption.

\section{Keywords}

Ukraine, policy, environment, protection, legislation, Constitution, the law, strategy, action plan, European integration.
\end{abstract}

\section{UWAGI WSTĘPNE}

Rozwój demokratycznej i stabilnej Ukrainy, jako drugiego pod względem powierzchni państwa w Europie, ma znaczenie szczególne dla bezpieczeństwa Europy. Z uwagi na bezpośrednie sąsiedztwo Polski z Ukrainą i strategiczne cele polityki Warszawy wobec Kijowa związane z integracją Ukrainy z Unią Europejską, 
czynnik ten jest trudny do przecenienia z polskiego punktu widzenia.

Dramatyczne karty najnowszej historii Ukrainy i oparty na energochłonnych sektorach system gospodarki zmuszają, przy analizie sytuacji wewnętrznej w tym kraju, do zwrócenia szczególnej uwagi na stan środowiska. Niestety, największy sąsiad Polski nie może się nim pochwalić. Antropogeniczne oddziaływanie na środowisko naturalne na Ukrainie kilkakrotnie przewyższa analogiczny poziom w krajach rozwiniętych. Średnia długość życia nad Dnieprem stanowi 66 lat (w Szwecji - 80, a w Polsce - 74 lata), co świadczy m.in. o złej sytuacji ekologicznej w tym kraju ${ }^{1}$.

Wśród kluczowych przyczyn takiego stanu rzeczy wymienianych jest kilka czynników. Pierwszym jest odziedziczona po Związku Radzieckim struktura gospodarki kraju z nadmiernie rozbudowanymi gałęziami przemysłu, które wykorzystują niewspółmierne do efektów swojej pracy wielkości surowców. Dotyczy to zwłaszcza sektorów metalurgicznego i chemicznego, które są podstawą systemu ekonomicznego kraju. Rozpoczęta po uzyskaniu niepodległości w 1991 roku chaotyczna transformacja ustrojowa tylko zwiększyła wpływ tego czynnika na stan środowiska naturalnego nad Dnieprem. Niemniej istotne skutki dla środowiska Ukrainy ma przestarzała infrastruktura przemysłowa i transportowa, które znacząco odbiegają od standardów krajów Europy Zachodniej i Środkowej. Innym aspektem generującym problemy jest nieefektywny system zarządzania, który nie przewiduje przejrzystego podziału funkcji i odpowiedzialności organów władzy za gospodarowanie i ochronę obiektów ${ }^{2}$.

Szanse na szybką zmianę tendencji odnośnie ochrony środowiska na Ukrainie minimalizuje słabość społeczeństwa obywatelskiego. Dodatkowo, poziom świadomości społecznej w zakresie poprawy sytuacji ekologicznej jest niski. Mieszkańcy Ukrainy nie doceniają znaczenia tej kwestii dla kraju, a także dla samych

1 Закон України Про Основні засади (стратегію) державної екологічної політики України на період до 2020 року; patrz: strona internetowa Rady Najwyższej Ukrainy: http://zakon.rada.gov.ua/cgi-bin/laws/m ain.cgi?nreg $=2818-17 ; 17.09 .2011$.

2 Tamże. 
siebie. Czynnik ten jest niemałym paradoksem ze względu na stosunkowo świeży dramat awarii elektrowni atomowej w Czarnobylu oraz regularnie powtarzające się katastrofy i awarie przemysłowe.

Wreszcie, wśród przyczyn daleko niezadowalającego stanu środowiska nad Dnieprem trzeba wymienić brak restrykcyjnego przestrzegania prawodawstwa regulującego jego ochronę. Właśnie ten ostatni czynnik jest poddany poniżej analizie.

\section{OCHRONA ŚRODOWISKA NA UKRAINIE W S'WIETLE PRZEPISOW KONSTYTUCJI UKRAINY Z 1996 R. ORAZ USTAWY O OCHRONIE ŚRODOWISKA NATURALNEGO Z $1991 \mathrm{R}$.}

O podstawowych prawach obywateli i obowiązkach państwa w zakresie omawianego tematu wspomina ukraińska ustawa zasadnicza. Zgodnie z jej art. 16 państwo jest zobowiązane do zapewnienia bezpieczeństwa ekologicznego i podtrzymywania równowagi ekologicznej na terytorium Ukrainy. Innymi zadaniami państwa ma być likwidacja skutków katastrofy w Czarnobylu oraz zachowanie zasobu genetycznego narodu ukraińskiego ${ }^{3}$. Prawa obywateli Ukrainy określa art. 50 Konstytucji - są nimi prawo do bezpiecznego dla zdrowia i życia środowiska naturalnego i odszkodowania za poniesione straty oraz prawo do uzyskiwania informacji na temat stanu środowiska w kraju i jakości produktów spożywczych. Taka informacja nie może zostać objęta tajemnicą bez względu na okoliczności ${ }^{4}$.

Jeszcze przed uzyskaniem niepodległości Ukrainy, Rada Najwyższa Ukraińskiej Socjalistycznej Republiki Radzieckiej dnia 25 czerwca 1991 roku uchwaliła ustawę o ochronie środowiska

3 Конституиія України; patrz: strona internetowa Rady Najwyższej Ukrainy: http://zakon.rada.gov.ua/cgi-bin/laws/main.cgi?nreg=254\%EA\%2F96q/2011- -\%E2\%F0; 17.09.2011.

4 Tamże. 
naturalnego ${ }^{5}$. Akt ten był poddawany licznym nowelizacjom, z których ostatnia, według stanu na wrzesień 2011 roku, została uchwalona w czerwcu 2011 roku. W rozdziale pierwszym ustawy („Zasady ogólne”) określone zostały m.in. zadania władz publicznych w sferze ochrony środowiska. W artykule 2 zaliczono do nich: regulację stosunków w sektorze surowców naturalnych; zapewnienie bezpieczeństwa ekologicznego; likwidację negatywnych skutków działalności szkodzącej środowisku naturalnemu; zachowanie różnorodności biologicznej. Reszta artykułów poświęcona jest ogólnikowym regulacjom dotyczącym prawa własności obiektów objętych szczególną ochroną, oświaty i wychowania ekologicznego oraz badań naukowych.

Artykuł 9 tej ustawy poświęcony jest prawom obywateli. Pierwszym jest prawo do bezpiecznego dla zdrowia i życia środowiska. Kolejnym uprawnieniem jest możliwość udziału społeczeństwa w sprawach dotyczących przedsięwzięć mogących mieć negatywny wpływ na środowisko. Ustawa daje też prawo obywatelom do korzystania z surowców naturalnych, tworzenie organizacji stawiających sobie za cel ochronę środowiska, otrzymanie wykształcenia ekologicznego oraz uzyskiwanie informacji dotyczącej stanu środowiska naturalnego w kraju. Obywatele Ukrainy mogą też występować z pozwami sądowymi w celu otrzymania odszkodowania za poniesione straty w wyniku katastrof ekologicznych. Obowiązek zapewnienia wymienionych praw obywateli spoczywa na władzach publicznych, które reprezentowane są przez organy administracji publicznej wszystkich szczebli (art. 11). Ustawa określa również podstawowe obowiązki obywateli w zakresie ochrony środowiska (art. 12), takie jak: racjonalne wykorzystywanie surowców z przestrzeganiem obowiązujących praw, norm i limitów ekologicznych. Mieszkańcy

5 Закон України Про охорону навколишнього природного середовища; patrz: strona internetowa Rady Najwyższej Ukrainy: http://zakon.rada.gov. ua/cgi-bin/laws/main.cgi?nreg=1264-12; 17.09.2011. Ciekawostką jest to, że w dokumencie po dziś pozostawiono starą terminologię charakterystyczną dla Ukraińskiej Socjalistycznej Republiki Radzieckiej - w ustawie wielokrotnie powtarza się w odniesieniu do Ukrainy w różnych odmianach słowo „republika”. 
Ukrainy są zobowiązani także do kompensowania strat, które spowodowali w środowisku naturalnym.

$\mathrm{W}$ rozdziale trzecim ustawy określone zostały kompetencje poszczególnych organów władzy ustawodawczej w sferze ochrony środowiska. Wyłączną kompetencją Rady Najwyższej Ukrainy jest wyznaczanie ogólnych kierunków i zasad polityki ekologicznej państwa, zatwierdzanie programów i strategii państwowych oraz ustanawianie praw regulujących działalność w tym zakresie. Pozostałe rady niższych szczebli mają m.in. prawo do przyjmowania lokalnych programów ekologicznych, wydawania zgody na rozmieszczenie na terytoriach im podległych obiektów przemysłowych, zatwierdzania planów zasiedlania i budowy tych terenów, organizowania prac związanych z usuwaniem skutków katastrof ekologicznych, kontroli ekologicznych i wstrzymywania (tymczasowego) prac przedsiębiorstw o znaczeniu lokalnym łamiących prawo o ochronie środowiska ${ }^{6}$.

Kolejny rozdział ustawy z 1991 r. reguluje funkcje organów władzy wykonawczej w zakresie realizacji polityki ochrony środowiska. Ogólnymi funkcjami władzy wykonawczej są obserwacja, ocena oddziaływania na środowisko, kontrola, prognozowanie i badania ekologiczne. Zgodnie z art. 17 ustawy do zadań Gabinetu Ministrów Ukrainy (GMU) należą: realizacja zasad polityki wyznaczanej przez parlament, opracowywanie programów państwowych, koordynowanie działalności organów władzy wykonawczej, ustalanie norm i limitów ekologicznych. GMU ma też organizować prace poprawiające stan świadomości ekologicznej mieszkańców Ukrainy. Rząd Ukrainy podejmuje także decyzje dotyczące tymczasowego wstrzymywania pracy obiektów przemysłowych nieprzestrzegających prawa o ochronie środowiska ${ }^{7}$

6 Z uwagi na słabość samorządów terytorialnych na Ukrainie, kompetencje i możliwości lokalnych organów władzy są jednak ograniczone. Jest to spowodowane przede wszystkich archaicznym modelem finansowania samorządów przewidującym coroczny podział środków z centrali w Kijowie.

7 Takie prawo jest w praktyce właściwie niewykorzystywane. Np. większość zakładów przemysłowych znajduje się w rękach biznesmenów mających bezpośrednie wpływy w najwyższych szczeblach władzy. Takie kanały umożliwiają im unikanie kar za oczywiste naruszenia prawa. 
Lokalne władze wykonawcze realizują politykę określoną przez organy ustawodawcze i rząd centralny. Do ich kompetencji należy również koordynowanie prac lokalnych związanych z ochroną środowiska, np. zbiórki, przetwarzania i unieszkodliwania materiałów szkodliwych dla środowiska. Organizują także akcje informacyjne mające na celu poprawę poziomu świadomości ekologicznej obywateli.

W oddzielnym rozdziale ustawy uregulowane zostały instrumenty służące obserwacji, prognozowania i informowania społeczeństwa na temat stanu środowiska Ukrainy. Ustawa przewiduje utworzenie państwowego systemu monitoringu środowiska. Dla realizacji tego zadania w ustawie przewidziano powołanie specjalnego organu państwowego. Zgodnie z dekretem Prezydenta Ukrainy z 13 kwietnia 2011 r. jest nim Państwowa Inspekcja Ekologiczna (PIE). PIE jest centralnym organem władzy wykonawczej, którego działalność ukierunkowuje i koordynuje Minister Ekologii i Surowców Naturalnych. PIE jest również powołana do prowadzenia krótko i długookresowych prognoz zmian $\mathrm{w}$ środowisku ${ }^{8}$. Ustawa zobowiązuje przedsiębiorstwa niezależnie od formy własności do przekazywania PIE informacji dotyczących wskaźników produkcji mających wpływ na stan środowiska (art. 22). Szczególną uwagę w ustawie poświęcono najbardziej niebezpiecznym z ekologicznego punktu widzenia obiektom (art. 24). Warto jednak zaznaczyć, że brakuje efektywnego mechanizmu zbioru informacji - przedsiębiorstwa bowiem mają same przekazywać informacje analityczne PIE. Jednocześnie brakuje zapisów dotyczących odpowiedzialności za podanie nieprawdziwych danych. Wyniki przekazywane PIE podlegają obowiązkowemu upublicznieniu.

W rozdziale szóstym ustawy z 1991 r. ujęto regulacje odnoszące się do zagadnienia oceny oddziaływania na środowisko, za przeprowadzenie której odpowiedzialna ma być PIE. Podlegają jej plany rozwojowe sektorów gospodarki (istotnych z ekologicznego punktu widzenia), strategie zasiedlania terytoriów, projek-

8 Указ Президента Украӥни Про Положення про Державну екологічну інспекиію України; patrz: strona internetowa Rady Najwyższej Ukrainy: http:// zakon.rada.gov.ua/cgi-bin/laws/main.cgi?nreg=454\%2F2011; 17.09.2011. 
ty aktów prawnych mogących mieć wpływ na stan środowiska, dokumenty związane $\mathrm{z}$ zastosowaniem nowych technologii, środków sztucznych i urządzeń technicznych, a także budynki $\mathrm{i}$ inne obiekty potencjalnie niebezpieczne dla środowiska. Wyniki oceny są wiążące - brak pozytywnych wniosków w niej zawartych jest jednoznaczny z zakazem dalszego funkcjonowania danego obiektu czy realizacji planu (art. 27-29). Oprócz ocen prowadzonych przez PIE, w art. 30 ustawy odniesiono się do niezależnej oceny, prowadzonej przez instytucje społeczeństwa obywatelskiego. Jej rezultaty mogq być brane pod uwage przez organy państwowe.

Osobny rozdział ustawy poświęcony został standaryzacji i normowaniu ekologicznemu (art. 31-33). Standardy ekologiczne określają podstawowe pojęcia, terminy, sposoby wykorzystywania i metody kontroli w sferze ochrony środowiska, które muszą być przestrzegane. Normy ekologiczne dotyczą granicznych ilości odpadów i zanieczyszczeń, które mogą być odprowadzane do środowiska. Ustalaniem standardów i norm ekologicznych zajmuje się PIE.

W kolejnym rozdziale ustawy uregulowane zostały mechanizmy kontroli w zakresie ochrony środowiska (art. 38-40). Za jej przeprowadzenie odpowiedzialne są rady wszystkich szczebli i ich organy wykonawcze, a także PIE. Oprócz kontroli państwowej, ustawa przewiduje kontrolę ze strony trzeciego sektora. Rezultaty kontroli państwowej i obywatelskiej są do dyspozycji prokuratury wszystkich szczebli. Na ich podstawie może zostać wszczęte postępowanie karne.

Zgodnie z ustawą realizacja zadań organów państwowych w sferze ochrony środowiska jest finansowana ze środków budżetu centralnego i lokalnych (art. 41-47). Jednocześnie, w akcie tym przewidziano finansowanie innymi legalnymi sposobami projektów na rzecz ochrony środowiska na Ukrainie. Praktycznym krokiem ku realizacji tego punktu jest funkcjonowanie Państwowej Agencji Inwestycji Ekologicznych (PAIE), którą powołano do życia dekretem Prezydenta Ukrainy z 13 kwietnia 2011 r. Jej działalność nadzoruje i koordynuje Minister Ekologii i Surowców Naturalnych. Głównym zadaniem Agencji ma 2/2011 być przyciąganie inwestycji mających poprawić stan środowi- 
ska9. Warto zwrócić uwagę, że w warunkach niezbyt stabilnej ogólnej sytuacji budżetowej na Ukrainie, zwłaszcza po przejściu kryzysu finansowego, a także z uwagi na mało sprzyjający klimat inwestycyjny nad Dnieprem, takie źródła finansowania projektów na rzecz ochrony środowiska znacząco ograniczają możliwości ich udanej realizacji.

Ze względu na specyfikę problemów z egzekwowaniem prawa ochrony środowiska na Ukrainie, istotne znaczenie ma rozdział XV ustawy („Odpowiedzialność za naruszenie prawa ochrony środowiska"). W artykule 68 tego aktu wskazano na liczne przykłady naruszenia prawa ochrony środowiska. Wyróżnić można cztery rodzaje odpowiedzialności: dyscyplinarną, administracyjną, cywilną i karną. W ustawie uregulowano odpowiedzialność za dokonane naruszenia oraz sposoby kompensacji. Jednak zdaniem większości ukraińskich ekspertów, niski poziom dyscypliny $\mathrm{w}$ zastosowaniu nienagannych podstaw teoretycznych jest jedną z głównych przyczyn złego stanu środowiska w kraju. Sugeruje to, że kluczowym problemem z punktu widzenia ochrony środowiska na Ukrainie nie jest zły stan prawa, a inne czynniki.

\section{OCHRONA ŚRODOWISKA NA UKRAINIE W ŚWIETLE AKTU PT.: „GŁÓWNE ZASADY (STRATEGIA) PAŃSTWOWEJ POLITYKI EKOLOGICZNEJ UKRAINY DO 2020 ROKU” ORAZ AKTU PT.: „NARODOWY PLAN DZIAŁAŃ Z OCHRONY ŚRODOWISKA NATURALNEGO NA LATA 2011-2015"}

Kolejnym podstawowym dokumentem regulującym politykę państwa w sferze ochrony środowiska na Ukrainie jest akt pt.:

9 Указ Президента Украӥни Про Положення про Державне агентство екологічних інвестицій України; patrz: strona internetowa Państwowej Agencji Inwestycji Ekologicznych Ukrainy: http://neia.gov.ua/nature/co ntrol/uk/publish/article?art_id=126608\&cat_id=108499; 17.09.2011. 
„Główne zasady (Strategia) państwowej polityki ekologicznej Ukrainy do 2020 roku” (dalej cyt.: „Strategia”), przyjęty dnia 21 grudnia 2010 r. ${ }^{10}$ Rozdział pierwszy tego aktu poświęcony został analizie ogólnego stanu środowiska na Ukrainie. Następny rozdział dotyczy celów i zasad narodowej polityki ekologicznej. Za jej główny cel uznano stabilizację i poprawę stanu środowiska naturalnego Ukrainy poprzez integracje polityki ekologicznej z rozwojem społeczno-ekonomicznym państwa. Do podstawowych zasad polityki państwa w akcie tym zaliczono zwiększenie roli zarządzania ekologicznego w systemie służby publicznej w celu uzyskania równowagi między czynnikami rozwoju kraju: ekonomicznym, środowiskowym i społecznym. Reszta zasad jest powtórzeniem zapisów Konstytucji Ukrainy i ustawy o ochronie środowiska naturalnego z 1991 r., które regulują prawa i obowiązki obywateli i państwa w tym zakresie.

Kluczowym elementem „Strategii” wydaje się być treść rozdziału trzeciego, który wyznacza cztery priorytety polityki państwa w sferze ochrony środowiska. Z uwagi na ogólnikowy zarys celów polityki ekologicznej zawarty w Konstytucji Ukrainy i ustawie o ochronie środowiska naturalnego, wskazanie jej celów nadrzędnych było pożądane. Za pierwszy priorytet uznano poprawę poziomu świadomości ekologicznej społeczeństwa. „Strategia” wyznacza szereg zadań służących osiągnięciu tego celu. Do najważniejszych zaliczono:

1. Stworzenie narodowego systemu informacji o ochronie środowiska;

2. Zwiększenie ilości przekazów medialnych na tematy ochrony środowiska do 2015 roku - o 15\%, a do roku 2020 o 30\% (od stanu w 2010 roku);

3. Opracowanie do 2015 roku i początek realizacji „Strategii oświaty ekologicznej";

4. Opracowanie i wdrożenie w życie do 2015 roku systemu dokształcania ekologicznego pracowników administracji publicznej;

10 Закон України Про Основні засади (стратегію)... 
5. Tworzenie regionalnych informacyjnych centrów ekologicznych;

6. Tworzenie lokalnych centrów specjalizujących się w promocji i pomocy we wdrażaniu bezpiecznych dla środowiska technologii przemysłowych, rolniczych itp.

Drugim priorytetem „Strategii” jest poprawa sytuacji i poziomu bezpieczeństwa ekologicznego państwa ukraińskiego. Ten dosyć ogólnikowo sformułowany cel zawiera jednak w sobie kilka konkretnych założeń, które mają być zgodne z Planem działań z Johannesburga ${ }^{11}$. Kluczowymi zadaniami są tu: zmniejszenie ilości zanieczyszczeń w powietrzu atmosferycznym o 10\% do 2015 roku i o $25 \%$ do 2020 roku; wprowadzenie dla produktów naftowych i gazowych obowiązkowych standardów Euro-4 do 2015 roku i Euro-5 do 2020 roku; stopniowe zmniejszanie norm dopuszczalnych obecności w powietrzu atmosferycznym niebezpiecznych związków chemicznych; oraz zwiększenie w strukturze systemu energetycznego państwa źródeł z niskim poziomem emisji dwutlenku węgla: do 2015 roku - o 10\% i do 2020 roku - o 20\%. Ponadto wśród zadań priorytetu drugiego „Strategii” wskazano na zmniejszenie do 2020 roku o 15\% ilości ścieków komunalnych, zmniejszenie o ok. 5-10\% do 2020 roku powierzchni gruntów rolnych przy równoległym zwiększeniu zalesienia terytorium Ukrainy o 17\%. Do kluczowych celów tego priorytetu należy także zaliczyć: opracowanie nowego systemu koordynacji organów władzy wszystkich szczebli w na wypadek sytuacji nadzwyczajnych, zwiększenie do 2020 roku o 1,5 razy zastosowania odpadów jako surowców wtórnych i zapewnienie do 2020 roku środków alternatywnych względem niebezpiecznych pestycydów celem ich wycofania.

Priorytet trzeci „Strategii” dotyczy zapewnienia bezpiecznego dla zdrowia ludzkiego stanu środowiska. Kluczowymi celami w ramach tego priorytetu mają być:

1. Utworzenie do 2015 roku automatycznego systemu kontroli jakości powietrza i zapewnienie zbiorczych systemów ka-

11 Szczyt w Johannesburgu - Plan działania; patrz: strona internetowa „Johannesburg Summit 2002": http://www.unic.un.org.pl/johannesburg/plan_ dzialania.php; 17.09.2011. 
nalizacji i oczyszczalni ścieków w miastach z liczbą mieszkańców powyżej 250 tys.;

2. Wprowadzenie do 2020 roku systemu certyfikacji ekologicznej produktów spożywczych;

3. Rozszerzenie zakresu tematycznego o kwestie sanitarno-epidemiologiczne $\mathrm{w}$ programach oświatowych dla pracowników administracji publicznej;

4. Rozwój do 2015 roku bazy prawnej regulującej aspekty związane z kompensacją materialną (ubezpieczeniem zdrowotnym) obywateli uzyskiwaną na skutek strat spowodowanych przez środowisko naturalne.

Ostatni priorytet „Strategii” nosi nazwę: „Integracja polityki ochrony środowiska i udoskonalenie centralnego systemu zarządzania ekologicznego". Wśród konkretnych celów wskazanych w ramach tego priorytetu warto wymienić obowiązkowe włączanie zasad polityki ochrony środowiska w sektorowych programach rozwojowych; opracowanie i wprowadzenie w życie do 2015 roku systemu zachęt do wprowadzania bezpiecznych dla środowiska rozwiązań technologicznych; uchwalenie do 2012 roku „Koncepcji rozwoju czystej produkcji” i wprowadzenie jej w życie do 2015 roku; budowa do 2015 roku ekranów akustycznych w pobliżu budynków mieszkalnych znajdujących się przy autostradach w miastach z liczbą mieszkańców powyżej 500 tys. oraz do 2020 roku w miastach z liczba mieszkańców powyżej 250 tys.; oraz zwiększenie do 2020 roku udziału komunikacji publicznej w sektorze transportowym o 25\%.

Do słabych punktów „Strategii” zaliczyć należy, po pierwsze, brak listy konkretnych działań, które mają doprowadzić do uzyskania celów w niej zawartych, co sprawia, że dokument wygląda jak lista życzeń. Po drugie, „Strategia” nie precyzuje ani konkretnych wykonawców zadań ani źródeł ich finansowania.

Wady „Strategii”, o których mowa powyżej, zostały zniwelowane wraz z przyjęciem w dniu 25 maja 2011 roku aktu, jaki jest „Narodowy plan działań na rzecz ochrony środowiska naturalnego na lata 2011-2015” („Plan działań”) ${ }^{12}$. Plan działań prze-

12 Розпорядження Кабінету Міністрів України Про затвердження Національного плану дій з охорони навколишнього природного середовища України 
widuje dla każdego z priorytetów szereg zadań, które przydziela odpowiednim wykonawcom. Ponadto, Plan działań określa dokładne terminy ich realizacji oraz orientacyjną wartość i źródła finansowania. Dokument należy ocenić jednoznacznie pozytywnie, choć pozostaje wiele pytań o realne możliwości wdrożenia w życie zawartych tam założeń. Chodzi zwłaszcza o możliwości finansowe Ukrainy.

\section{PROBLEM UNIJNEJ DYREKTYWY 2001/80/WE}

W dniu 7 października 2009 roku Ukraina sukcesem zakończyła negocjacje z Europejską Wspólnotą Energetyczną (EWE) na temat wstąpienia do tej organizacji ${ }^{13}$. Decyzję o przyłączeniu Ukrainy Wspólnota podjęła dnia 18 grudnia 2010 roku na spotkaniu Rady Ministrów w Zagrzebiu ${ }^{14}$. Ukrainę przyjęto wierząc obietnicom Kijowa, że ten przeprowadzi w określonych terminach szereg reform sektora energetycznego. Takie przemiany są jednym z kluczowych punktów mogących pomóc w poprawie stanu środowiska na Ukrainie. Najważniejszym elementem warunków jest implementacja dyrektywy 2001/80/WE Parlamentu Europejskiego i Rady z dnia 23 października 2001 r. w sprawie ograniczenia emisji niektórych zanieczyszczeń do powietrza z dużych obiektów energetycznego spalania ${ }^{15}$

на період 2011-2015 роки; patrz: strona internetowa Rady Najwyższej Ukrainy: http://zakon.rada.gov.ua/cgi-bin/laws/main.cgi?nreg=577-2011-\%F0; 17.09.2011.

13 Decision 2009/04/MC-EnC on the accession of Ukraine to the Energy Community Treaty; patrz: strona internetowa Europejskiej Wspólnoty Energetycznej: http://www.energy-community.org/pls/portal/docs/490178.PDF; 13.05.2010.

${ }_{14}$ Рада Міністрів Енергетичного Співтовариства прийняла одноголосне рімення про вступ України до цісї організацї̈; patrz: strona internetowa Ministerstwa Paliwa i Energetyki Ukrainy: http://mpe.kmu.g ov.ua/fuel/control/ $\mathrm{uk} /$ publish/printable_article?art_id $=165842 ; 13.05 .2010$.

15 Dz. Urz. UE L 309 z 27.11.2001, s. 1-21 ze zm. 
Formalnie Kijów przeprowadził zmiany w ustawodawstwie, które dostosowały bazę prawną do wymogów dyrektywy. Częściowo dokonano tego zresztą jeszcze przed ukończeniem negocjacji z EWE. Zgodnie z decyzją o przyjęciu Ukrainy do EWE dyrektywa musi zostać implementowana w całości do 1 stycznia 2018 r. Zdaniem niektórych ośrodków biznesowych, na których interesy wpływają zapisy dyrektywy, realny termin jej wprowadzenia w życie to lata 2025-203016. Do głównych przyczyn takiego opóźnienia należy brak środków finansowych na modernizację obiektów przemysłowych potęgowany przez niegotowość (bądź niechęć) organów państwowych do egzekwowania wymogów dyrektywy. Większość ukraińskich ekspertów podkreśla, że istnieje bardzo duże prawdopodobieństwo niedotrzymania zakładanego terminu. Przypadek dyrektywy 2001/80/WE - wprowadzenie zmian w ustawodawstwie bez większych szans na ich przestrzeganie - pokazuje, że w warunkach ukraińskich nawet idealnie skonstruowana baza prawna nie zagwarantuje jej egzekwowania. Tym samym należy stwierdzić, że oceniając zasady prawne polityki Ukrainy w sferze ochrony środowiska naturalnego, warto analizować ten problem nieco szerzej.

\section{PODSUMOWANIE}

Podstawy prawne polityki państwowej w sferze ochrony środowiska są dosyć okazałe. Generalnie odpowiadają potrzebom i wyzwaniom stojącym przed Kijowem w procesie poprawy stanu środowiska Ukrainy. Mimo znaczących sukcesów w tworzeniu ustawodawstwa regulującego sferę ochrony środowiska, jego stan nad Dnieprem pozostaje daleko niezadowalający. Jednak przyczyn tego należy doszukiwać się nie tyle w bazie praw-

16 І.Газізуллін, В.Вільямс, Л.Лозовий, Аналітичний звіт "Готовність Украӥни до інтетрачіï у Свропейське Енергетичне Співтовариство; patrz: strona internetowa Międzynarodowego Centrum Badań Perspektywicznych: http://www.icps.com.ua/key_issues/energy.html ; 17.09.2011. 
nej regulującej sferę ochrony środowiska, co w skuteczności w jej egzekwowaniu.

Większość ekspertów zajmujących się integracją Ukrainy z Unią Europejską jest zdania, że kluczowymi problemami na szlaku Kijowa do Brukseli są wszechobecna korupcja oraz niewydolność organów państwowych różnych szczebli. Opinie te znajduja potwierdzenie w corocznych raportach Komisji Europejskiej badającej postępy reform w krajach sąsiedzkich UE, do których należy Ukraina. W takich warunkach, nawet najbardziej doskonałe regulacje prawne nie pozwolą zrealizować oficjalnych celów polityki ochrony środowiska deklarowanych przez państwo ukraińskie.

Osobną kwestią jest obecność woli politycznej (czy raczej jej brak) władz Ukrainy do przeprowadzenia gruntownych zmian i restrykcyjnego przestrzegania zasad prawnych dotyczących polityki ochrony środowiska. Należy pamiętać, że większość właścicieli obiektów przemysłowych podlegających modernizacji posiada silne wpływy na szczytach władzy. Takie możliwości pozwalają na unikanie odpowiedzialności za naruszenia prawa i inne działania destrukcyjne, które skutecznie hamują kroki sprzyjające poprawie stanu środowiska na Ukrainie. Tendencje te umacnia słabość ukraińskiego społeczeństwa obywatelskiego, które nie tylko nie jest w stanie wpłynąć na zmiany, ale też nie uświadamia sobie jak na razie w sposób właściwy wagi tego problemu.

\section{BIBLIOGRAFIA}

Decision 2009/04/MC-EnC on the accession of Ukraine to the Energy Community Treaty; patrz: strona internetowa Wspólnoty Energetycznej: http://www.energy-community.org/pls/portal/ docs/490178.PDF; 13.05.2010.

Dyrektywa 2001/80/WE Parlamentu Europejskiego i Rady z dnia 23 października 2001 r. w sprawie ograniczenia emisji niektórych zanieczyszczeń do powietrza z dużych obiektów energetycznego spalania, Dz. Urz. UE L 309 z 27.11.2001, s. 1-21 ze zm. 
І.Газізуллін, В.Вільямс, Л.Лозовий, Аналітичний звіт “Готовність Украӥни до інтетрачіі у Європейське Енергетичне Співтовариство; patrz: strona internetowa Międzynarodowego Centrum Badań Perspektywicznych: http://www.icps.com.ua/ key_issues/energy.html; 17.09.2011.

Конституція України; patrz: strona internetowa Rady Najwyższej Ukrainy: http://zakon.rada.gov.ua/cgi-bin/laws/main.cgi?nre$\mathrm{g}=254 \% \mathrm{EA} \% 2 \mathrm{~F} 96-\% \mathrm{E} \% \mathrm{~F} 0 ; 17.09 .2011$.

Рада Міністрів Енергетичного Співтовариства прийняла одноголосне рішення про вступ України до ичієї організації; patrz: strona internetowa Ministerstwa Paliwa i Energetyki Ukrainy: http:// mpe.kmu.gov.ua/fuel/control/uk/publish/printab le_article?art_id=165842; 13.05.2010.

Розпорядження Кабінету Міністрів України Про затвердження Національного плану дій з охорони навколишнього природного середовища України на період 2011-2015 роки; patrz: strona internetowa Rady Najwyższej Ukrainy: http://zakon.rada.gov.ua/cgi-bin/ laws/main.cgi?nreg=577-2011-\%F0; 17.09.2011.

Szczyt $w$ Johannesburgu - Plan działania; patrz: strona internetowa Johannesburg Summit 2002: http://www.unic.un.org.pl/johannesburg/plan_dzialania.php; 17.09.2011.

Указ Президента України Про Положення про Державне агентство екологічних інвестицій України; patrz: strona internetowa Państwowej Agencji Inwestycji Ekologicznych Ukrainy: http://neia.gov.ua/nature/control/uk/publi sh/article?art_ id=126608\&cat_id=108499; 17.09.2011.

Указ Президента України Про Положення про Державну екологічну інспекиію Украӥни; patrz: strona internetowa Rady Najwyższej Ukrainy: http://zakon.rada.g ov.ua/cgi-bin/laws/main.cgi?nre$\mathrm{g}=454 \% 2 \mathrm{~F} 2011 ; 17.09 .2011$

Закон України Про охорону навколишнього природного середовищза; patrz: strona internetowa Rady Najwyższej Ukrainy: http:// zakon.rada.gov.ua/cgi-bin/laws /main.cgi?nreg=1264-12; 17.09.2011.

Закон України Про Основні засади (стратегію) державної екологічної політики Украӥни на період до 2020 року; patrz: strona internetowa Rady Najwyższej Ukrainy: http://zakon.rada.gov.ua/cgi-bin/ laws/m ain.cgi?nreg $=2818-17 ; 17.09 .2011$.

Kontakt e-mail

kost.iryna@gmail.com 